\title{
Assessing Soil Quality Indicators in El- Minya Governorate Using Integration between Gis and Remote Sensing \\ Rania M. Mohamed ${ }^{(1)}$,Heba. S. Rashed, ${ }^{(2)}$ Omer H.M.El-Hosany, ${ }^{(2)}$ Ibrahim Mohamed, ${ }^{(2)}$ Adel Shalaby, ${ }^{(1)}$ 1- Soil and water science department-faculty of Agricultural-Banha University. \\ 2- National Authority for Remote Sensing and Space Sciences, P.O. Box 1564, Alf Maskan, Cairo, Egypt
}

Corresponding Author: rmansour327@yahoo.com

\begin{abstract}
Soil quality assessing was done by integration between remote sensing and GIS for west El-Minya Governorate. The district is of high seniority for agriculture development. Twenty-five soil profiles were drilled to represent the main geomorphologic units within the investigated area. The result indicated that ten main morphological units were identified ,1- old wadi sediments, 2- Peniplains, 3-Old stream terraces, 4-Plains out wash, 5- Sand dunes, 6-Erosional plains, 7-Sand sheets, 8-hill, 9-Rock out crops, and 10-Shoulders. The soil quality index (SQI) was estimated depending on parent material, drainage condition, soil texture class, rock fragments (\%), soil depth $(\mathrm{cm})$,slope gradient $(\%), \mathrm{EC}(\mathrm{ds} / \mathrm{m}), \mathrm{ESP}, \mathrm{pH}$ and $\mathrm{CaCO} 3(\mathrm{~g} / \mathrm{kg})$.Soil of west El-Minya area variable from high soil quality to low soil quality and percentages were as follows: High quality areas index represent $7.0 \%$ of the total area (40021 ha) in RT mapping unit, most of the study area $88 \%$ (506401 ha) consists of moderate and moderate low quality classes in SH, WS, P, S, EP and PO mapping units, and low quality areas index represents $5 \%$ of the total area (26203ha) in RO, SD and $\mathrm{H}$ mapping units. The research additionally explain the significance of GIS in constructing land resource data base of soil that is very much substantial for better observance of soil characteristic for optimum sustainable agriculture.
\end{abstract}

Keywords: Soil quality, Remote sensing, GIS, El-Minya Governorate.

\section{Introduction}

Soils are a limited resource, cover majority of lands on the earth and could be renewable, (Blum, 2006). It is common knowledge that the soil is the main source in the provision of essential plant nutrients and water reserves and it is a means to grow the plant. According to (UNDP, 2007), Agriculture is the pillar of the economy in many countries, especially the developing countries, and it is considered one of the most vital activities that support human life. The definition of soil quality discovered in the going early 1990s (Wienhold et al., 2004) and defined as the ability of a soil to perform within an ecosystem and soil use, to preserve both of biological activities, and environmental quality, as well as encourage plants production (Karlenet al., 1997). Soil quality is the "capacity of a soil to function, within ecosystem and land-use boundaries, to sustain biological productivity, maintain environmental quality, thus and promote plant, animal and human health". Soil quality has two parts: an essential part covering its inherent ability for crop growth and a dynamic part affected by its user or manager. Dynamic soil quality changes in response to soil use and management (Pierzynski et al., 1994; Dumanski and Pieri, 2000; Blum, 2003 and Novak et al., 2010 and).Soil quality is considered one of the best methods for soil determination due to facility of use, resilience and quantification. These indicators perform the cumulative effects of different soil characteristic (physical and chemical) as an index from the part of each index in soil quality (Drury et al., 2003; and Khera, 2009). Soil quality includes both the productivity and environmental characteristics of the soil (Wander et al. 2002 Bone et al., 2010) also the capacity to resist and regain from degradation (Blum, 1998). Inherent soil quality can be estimate using land resource or soil survey inventories (MacDonald et al., 1995 and Soil Survey Staff, 2000). There is no standard method established to estimate soil quality indicator for major soils across the World in spite of a numerous attempts have been made to state a stander methodology of soil quality assessment (Atanu and Rattan, 2014).Remote sensing is the science and art of obtaining information, (Lillesand and Kiefer, 1994). Propagated signals of optical, acoustical, or microwave or others are employed in this concern (Khatami et al., 2016). Remote sensing imagery is an enormous tool for examine the surface of Earth, and covers great area with multiple spectra information and fixed observations (Mulder etal. 2011 and TaghizadehMehrjardi et al., 2014 and Rozenstein et al., 2016). Remote sensing is a significant technique for soil survey, mapping and environmental investigations (Sadeghi et al., 2015). The Geographic Information System (GIS) associates database systems for spatial data (Ekanayaki and Dayawansa, 2003). The combination between GIS and remote sensing has obtained much recognition as management tools for data collation and analysis (Rindfuss et al., 2004) Remote sensing and GIS are powerful, and costeffective tools for assessing spatial distribution and dynamics of land cover (Tottrup and Rasmussen, 2004; Wilson and Fotheringham, 2008; Dewan and Yamahuchi, 2009). The integration between remote sensing and GIS data with soil survey information developed for assessing soil quality (Abdel Rahman et al., 2018).

The current work aims at assessing soil quality potentials in El-Minya Governorate in view of soil physical and chemical characteristics as the well as 
biodiversity factors in Land surveying data, laboratory analyses, remote sensing and GIS were the main tools to obtain this objective.

\section{Materials and methods}

\section{Site description}

The study area is located between latitudes $27^{\circ} 55^{\prime}$ and $28^{\circ} 34^{\circ} \mathrm{N}$ and longitudes $29^{\circ} 44^{\circ}$ and $30^{\circ} 39^{\circ} \mathrm{E}$, at the western of River Nile as shown in Fig. 1. It covers around 572900hain El-Minya Governorate, Egypt. The area surrounded by River Nile in the East, the limestone plateau in the West, Beni-Suef Governorate in the North and Assiut Governorate in the South. ElMinya Governorate includes 9 districts, 54 main villages and 340 secondary villages. The total area of El-Minya Governorate is 3227900 ha, from which 3043900hais desert lands while the rest of the governorate is agricultural land. El-Minya is generally characterized by hot dry climate in summer and cold with few showers in winter. Fig. 2 shows the climatologically diagram of El-Minya which were obtained from El-Minya meteorological station within the period of $2002-2018$.
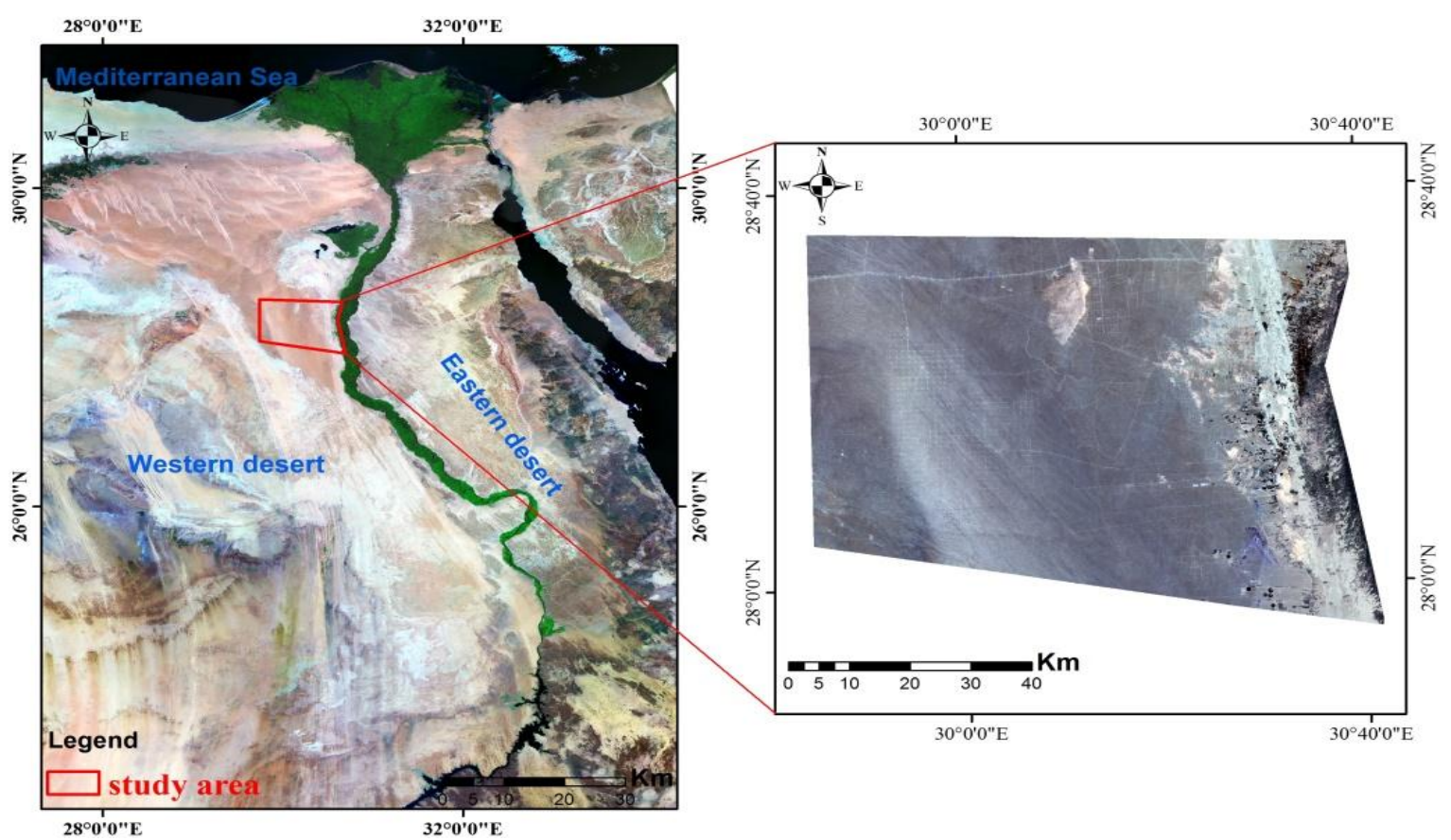

Fig. 1: Location map of the study area Climatic conditions.
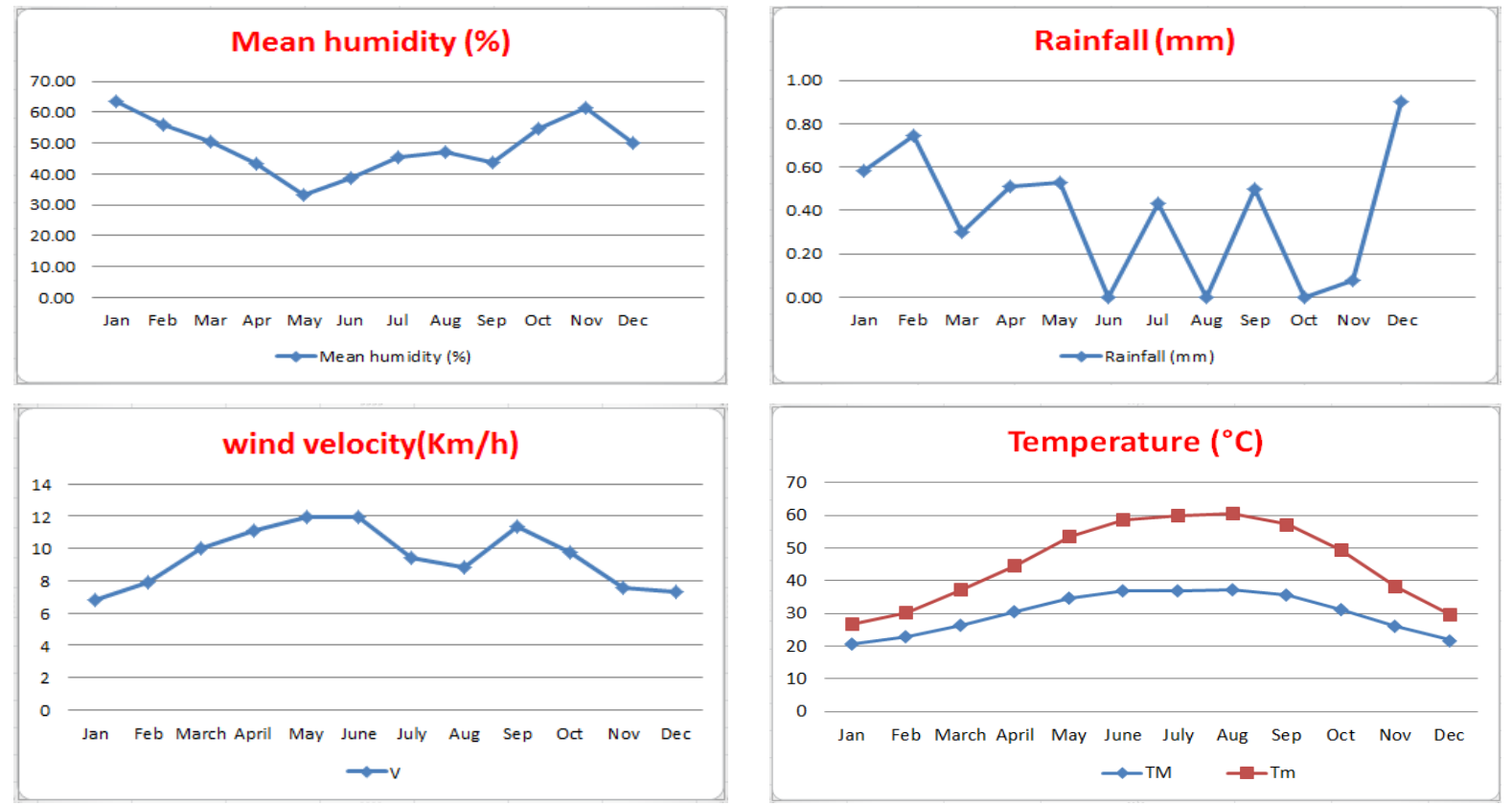

Fig. 2: Climatologically diagram of El-Minya Governorate 


\section{Geomorphology of the study area}

According to AbouHeleika and Niesner

(2008), there are three geomorphologic units dominated within the investigated area from west to east as follow:

a) The sedimentary rock plateau is structurally formed, collected principally of sedimentary rock plated with deposits of sands and stone and border the Nile River natural depression.

b) The old alluvial plain is neighbor to the geological formation of plateau and it contains new desert reclamation lands further as dispersed urban areas within the western side of the valley and it's irrigated by groundwater. c) The young alluvial plain, occupies the area neighbor to the Nile River bank between the River Nile and recent deposit plain.

\section{Geology of the study area}

The surface geological feature within the study area as following: a-Unconsolidated sands and gravels (Quaternary deposits) intercalated with clay lenses, b) Oligocene-Pleistocene gravel and sand, c) Quatrain Formation of Oligocene d) sedimentary rock of Smalt and Minya Formations (Mokattam sedimentary rock group), (Said, 1997and Abou Heleika and Niesner,2008).

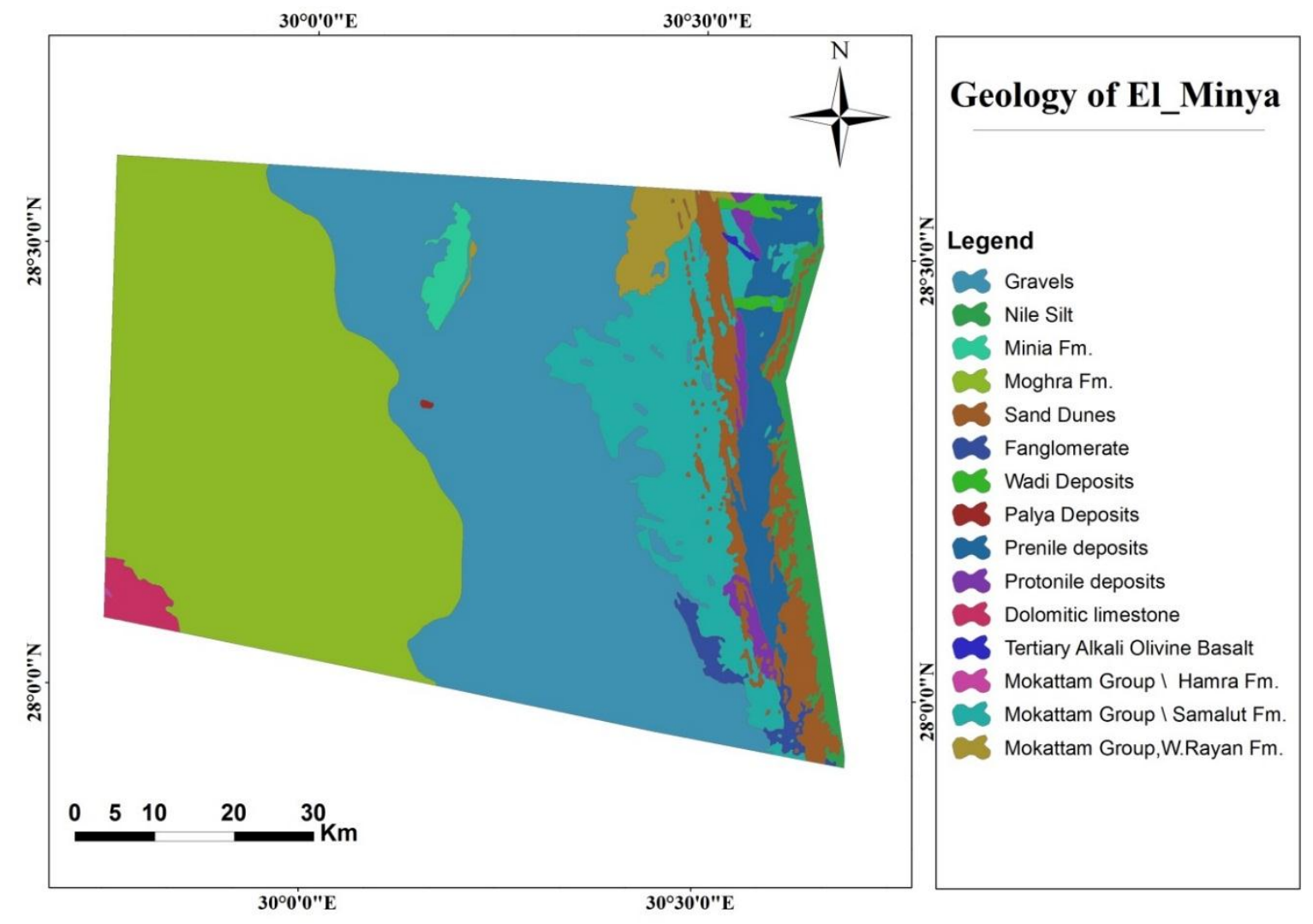

Fig. 3: Geological map of El-Minya (After Conoco, 1987).

\section{Image processing}

Remote sensing analyses of El-Minya Governorate used data from Landsat Data Continuity Mission (LDCM) sensor (Landsat-8) in 2018. All further digital image processing and analyses were executed using the standard approaches provided by the ENVI 5.2 and the Arc-GIS 10.3 software. Image processing included bad line manipulations by filling gaps module designed using IDL language and data calibration to radiance according to (Lille sand and Kiefer, 2007).

\section{Soil Taxonomy}

Based on climatically data (EMA, 2010), the soil temperature regime of El-Minya Governorate was defined as thermic and the soil moisture regime was defined as torricon basis of classification of the USD a Soil Taxonomy System (USDA, 2014). Soils were classified under one soil order, Entisols.

\section{Soil survey and field work.}

A semi detailed survey was carried out. Twenty-five soil profiles were taken to represent the main geomorphic units within the study area and the morphological features were outlined according to the FAO (2006). Soil samples were collected for laboratory analyses of some physical and chemical 
soil properties according to (USDA, 2004and Bandy opadhyay, 2007).

\section{Soil quality Index (SQI) Model and rating system}

Twenty five profiles were used to assess SQI in the studied area, including physical and chemicalproperties. Theseprofileswerecreatedinageog raphicinformationsystem(GIS)usingthespatialanalystt ool.TheLandsat-

8OLIimageoftheinvestigatedareaandthedigitalelevati onmodelwereusedtocreatethemainlandtypelayer,this profiles were used as a base map in the geographic information system. The SQI model was created by Kosmas et al. (1999) and Sepehr et al. (2007).

In the soil quality model, explanation criteria are modeled based on soil physical and chemical properties traditionally incorporate. In the present research, the model of Kosmas et al. (1999) and Sepehr et al. (2007).(Soil Quality Index, SQI) will be used. This model works interactively, comparing the values of the characteristics of the land unit with the generalization levels designated for each quality class. Soil quality model is based on analysis of edaphic factors which affect the quality. The following steps explain the mechanism of Soil Quality Index (SQI) model:

1-The edaphic factors including:

(i) The physical soil quality index was evaluated depending upon drainage condition (D) Rock fragments (R \%); slope gradient (S \%), soil texture class(T), soil depth (P cm), and parent material(M)are used as diagnostic criteria.

(ii) The chemical soil quality index was evaluated depending upon electrical conductivity ( $\mathrm{ds} / \mathrm{m})$, exchangeable sodium percentage $(\mathrm{E}), \mathrm{pH}(\mathrm{H})$ and calcium carbonate $(\mathrm{O} \mathrm{g} / \mathrm{kg})$ are used as diagnostic criteria.

2-Calculated the mean weighted value of each determined soil property in each mapping unit.

3- After the final data preparation, the physical and chemical properties were applied to Soil Quality Index (SQI) model to calculate the soil quality evaluation. The spatial analysis function in Arc GIS 10.3 was used to create thematic layers of the most constrained factors. The diagnostic factors of each thematic layer were assigned values of factor rating identified in Tables 2, 3, 4, 5 and 6.

4- The Soil Quality Index (SQI) was estimated for the different mapping units in the study area as:

$$
(\mathrm{SQI})=(\mathrm{T} \times \mathrm{M} \times \mathrm{D} \times \mathrm{P} \times \mathrm{S} \times \mathrm{R} \times \mathrm{H} \times \mathrm{C} \times \mathrm{E} \times \mathrm{O})^{1 / 10}
$$

5- Each factor is rated on a scale from 1 to 2 and the resultant index, lies between 1.2 and 1.5, and is set against a scale placing the soil in one of the following three quality classes. The rating of soil quality of the soils was done according to the grading system in Table 1.

Table1. Soil quality classes and rating

\begin{tabular}{cccc}
\hline \multirow{2}{*}{ Soil Quality Index } & Grade & Rating & Class \\
\cline { 2 - 4 } & I & $<1.2$ & High quality \\
& II & $1.2-1.25$ & Moderate quality \\
& III & $1.25-1.5$ & Moderate low quality \\
& IIII & $>1.5$ & Low quality \\
\hline
\end{tabular}




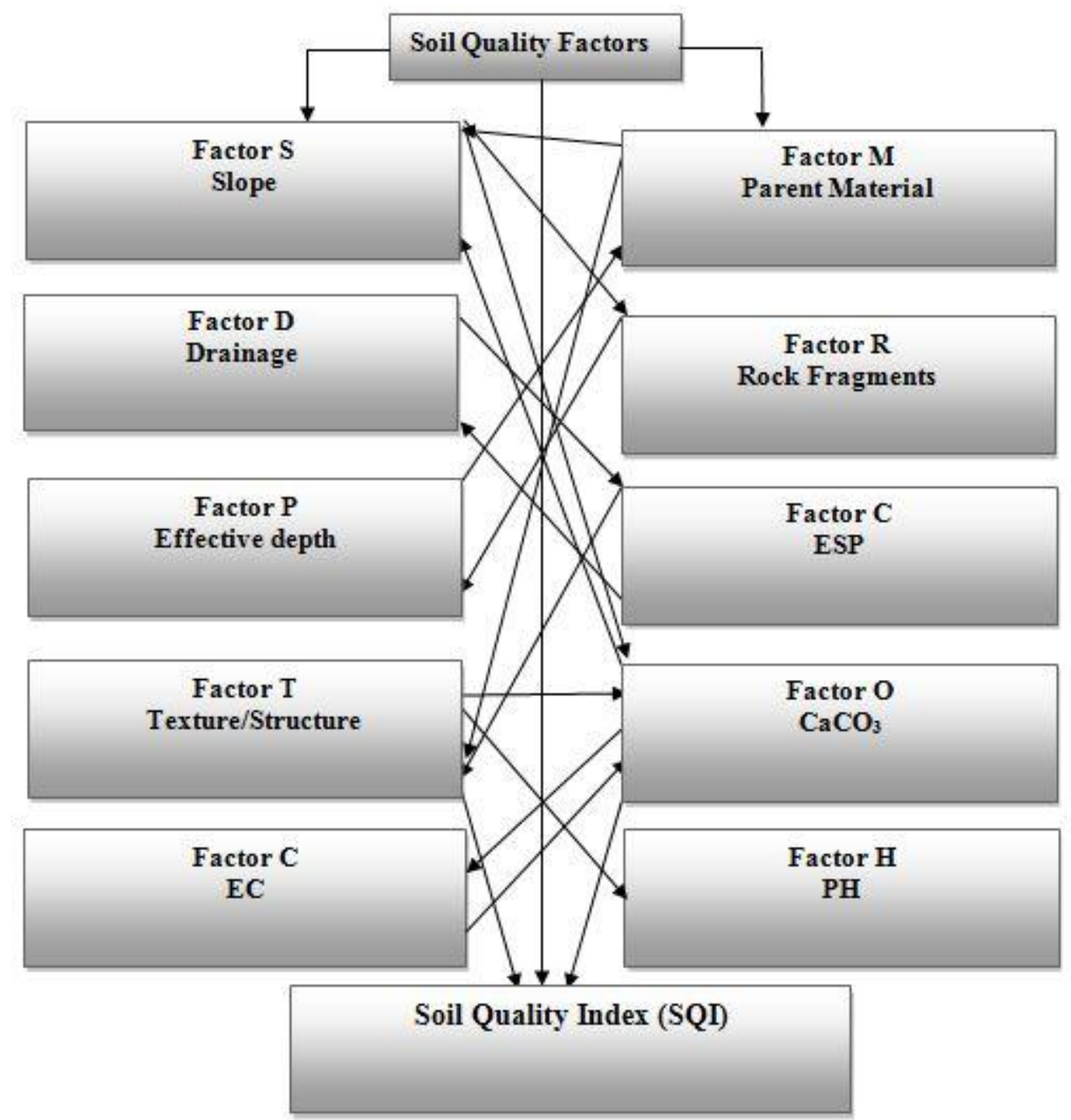

Fig. 4: Determination of Soil Quality index (SQI)

Table 2. Definition of soil texture and slope as soil quality parameters (Elnaggaret al., 2013)

\begin{tabular}{|c|c|c|c|c|c|c|c|c|}
\hline \multicolumn{4}{|c|}{ Soil Texture (T) } & \multicolumn{5}{|c|}{ slope $(\mathrm{S})$} \\
\hline $\mathbf{T}$ & $\begin{array}{c}\text { Descriptio } \\
\text { n }\end{array}$ & $\begin{array}{c}\text { Inde } \\
x\end{array}$ & $\begin{array}{c}\text { Clas } \\
\mathrm{s}\end{array}$ & Slope(S) & $\begin{array}{c}\text { Descriptio } \\
\text { n }\end{array}$ & $\begin{array}{c}\text { Clas } \\
\mathrm{s}\end{array}$ & Description & Index \\
\hline $\begin{array}{c}\mathbf{L}, \mathbf{S C L}, \mathbf{S L}, \mathbf{L S}, \\
\text { and CL }\end{array}$ & Good & 1.00 & 1 & $<6$ & $\begin{array}{l}\text { Very } \\
\text { Gentle }\end{array}$ & 1 & Very Gentle & 1.00 \\
\hline $\begin{array}{l}\mathrm{SC}, \mathrm{SiL} \text {, and } \\
\mathrm{SiCL}\end{array}$ & Moderate & 1.33 & 2 & $6-18$ & Moderately & 2 & Moderately & 1.33 \\
\hline $\mathrm{Si}, \mathrm{C}$, and $\mathrm{SiC}$ & Poor & 1.66 & 3 & $18-35$ & Steep & 3 & Steep & 1.66 \\
\hline $\mathbf{S}$ & Very Low & 2.00 & 4 & $>35$ & Very Steep & 4 & Very Steep & 2.00 \\
\hline
\end{tabular}

Note:L:loamy,SCL:sandclayloam,Sl:sandloam,LS:loamysand,CL:clay loam, SC: sandy clay,Sil:siltyloam,SiCL:siltyclayloam,Si:silty,c:clay,SiC:siltyclay,S;sand.

Table3. Definition of parent material and drainage as soil quality parameters (Elnaggaret al., 2013)

\begin{tabular}{|c|c|c|c|c|c|c|c|}
\hline \multicolumn{5}{|l|}{ Parent Material (P) } & \multicolumn{3}{|c|}{ Drainage (D) } \\
\hline$(\mathbf{P})$ & $\begin{array}{c}\text { Descriptio } \\
\text { n }\end{array}$ & Inde & Class & (D) & Description & Index & Clas \\
\hline $\begin{array}{l}\text { Limestone,dolomite,non- } \\
\text { friable,sandstone,hard limestone }\end{array}$ & coherent & 1.00 & 1.00 & $\begin{array}{l}\text { Well } \\
\text { Drainage }\end{array}$ & Good & 1.00 & 1.00 \\
\hline Marinelimestone, friable & Moderately & 1.66 & 2.00 & $\begin{array}{l}\text { Imperfectly } \\
\text { Drainage }\end{array}$ & Moderate & 1.33 & 2.00 \\
\hline
\end{tabular}


Table 4. Definition of soil depth and rock fragments as soil quality parameters (Elnaggaret al., 2013)

\begin{tabular}{cccccccc}
\hline & Depth $(\mathbf{P})$ & \multicolumn{5}{c}{ Rock fragments (R) } \\
\hline $\mathbf{( P )}$ & Description & Index & Class & $\mathbf{( R )}$ & Description & Index & Class \\
\hline $\mathbf{7 5}$ & Deep & 1.00 & 1 & $\mathbf{> 6 0}$ & Very stony & 1.00 & 1 \\
$\mathbf{3 0 - 7 0}$ & Moderately & 1.33 & 2 & $\mathbf{2 0 - 6 0}$ & Stony & 1.33 & 2 \\
$\mathbf{1 5 - 3 0}$ & Shallow & 1.66 & 3 & $<\mathbf{2 0}$ & Slightly stony & 2.00 & 3 \\
$<\mathbf{1 5}$ & Very shallow & 2.00 & 4 & - & - & - & - \\
\hline
\end{tabular}

Table 5. Definition of EC and ESP as soil quality parameters (Elnaggaret al., 2013)

\begin{tabular}{ccccccccc}
\hline \multicolumn{1}{c}{ EC $(\mathbf{d s} / \mathbf{m})$} & \multicolumn{7}{c}{ ESP } \\
\hline $\mathbf{C})$ & Description & Index & Class & $\mathbf{( E )}$ & Description & Index & Description & Class \\
\hline$<\mathbf{4}$ & Low & 1.00 & 1 & $<\mathbf{1 0}$ & Low & 1.00 & Low & 1 \\
$\mathbf{4 - 8}$ & Moderate & 1.33 & 2 & $\mathbf{1 0 - 1 5}$ & Moderate & 1.33 & Moderate & 2 \\
$\mathbf{8 - 1 6}$ & High & 1.66 & 3 & $\mathbf{1 5 - 2 0}$ & High & 1.66 & High & 3 \\
$<\mathbf{1 6}$ & Very high & 2.00 & 4 & $\mathbf{> 2 0}$ & Very high & 2.00 & Very high & 4 \\
\hline
\end{tabular}

Table 6. Definition of soil $\mathrm{pH}$ and $\mathrm{CaCO}_{3}$ as soil quality parameters (Elnaggaret al., 2013)

\begin{tabular}{cccccccc}
\hline & pH & \multicolumn{5}{c}{ CaCO $_{3}(\mathbf{O})$} \\
\hline pH & Description & Index & Class & $\mathbf{( O )}$ & Description & Index & Class \\
\hline $\mathbf{5 . 5 - 7}$ & Low & 1.00 & 1 & $<\mathbf{5 0}$ & Low & 1.00 & 1 \\
$\mathbf{7 - 7 . 8}$ & Moderate & 1.33 & 2 & $\mathbf{5 0 - 1 0 0}$ & Moderate & 1.33 & 2 \\
$\mathbf{7 . 8 - 8 . 5}$ & High & 1.66 & 3 & $\mathbf{1 0 0 - 1 5 0}$ & High & 1.66 & 3 \\
$>\mathbf{8 . 5}$ & Very high & 2.00 & 4 & $\mathbf{> 1 5 0}$ & Very high & 2.00 & 4 \\
\hline
\end{tabular}

\section{Results and discussion}

\section{Soil Taxonomy of the study area}

Soil Taxonomy of investigated area was done according to the soil Taxonomy Classification System of USDA (2014) .The soils belong to one order; Entisols. There is six units; Lithic Torripsamments represents the largest area $(61.3 \%)$ of study area followed by Typic Torripsamments (27.2\%) and finally Typic Torrifluvents(6.99). Hill, sand dunes and rock outcrops are restricted from the investigations based on landform analysis, field survey, and laboratory investigation.Table7and Figure5show the soils taxonomy of the study area.

Table 7. Soil Taxonomy of west El-Minya

\begin{tabular}{lcc}
\hline Soil Taxonomy & Area (ha) & Area (\%) \\
\hline TypicTorrifluvents & 40021.32 & 6.99 \\
TypicTorripsamments & 155530.8 & 27.2 \\
Lithic Torripsamments & 350869.8 & 61.3 \\
Rock Outcrops & 4792.6 & 0.8 \\
Sand Dunes & 13092.9 & 2.3 \\
Hill & 8317.2 & 1.5 \\
\hline
\end{tabular}




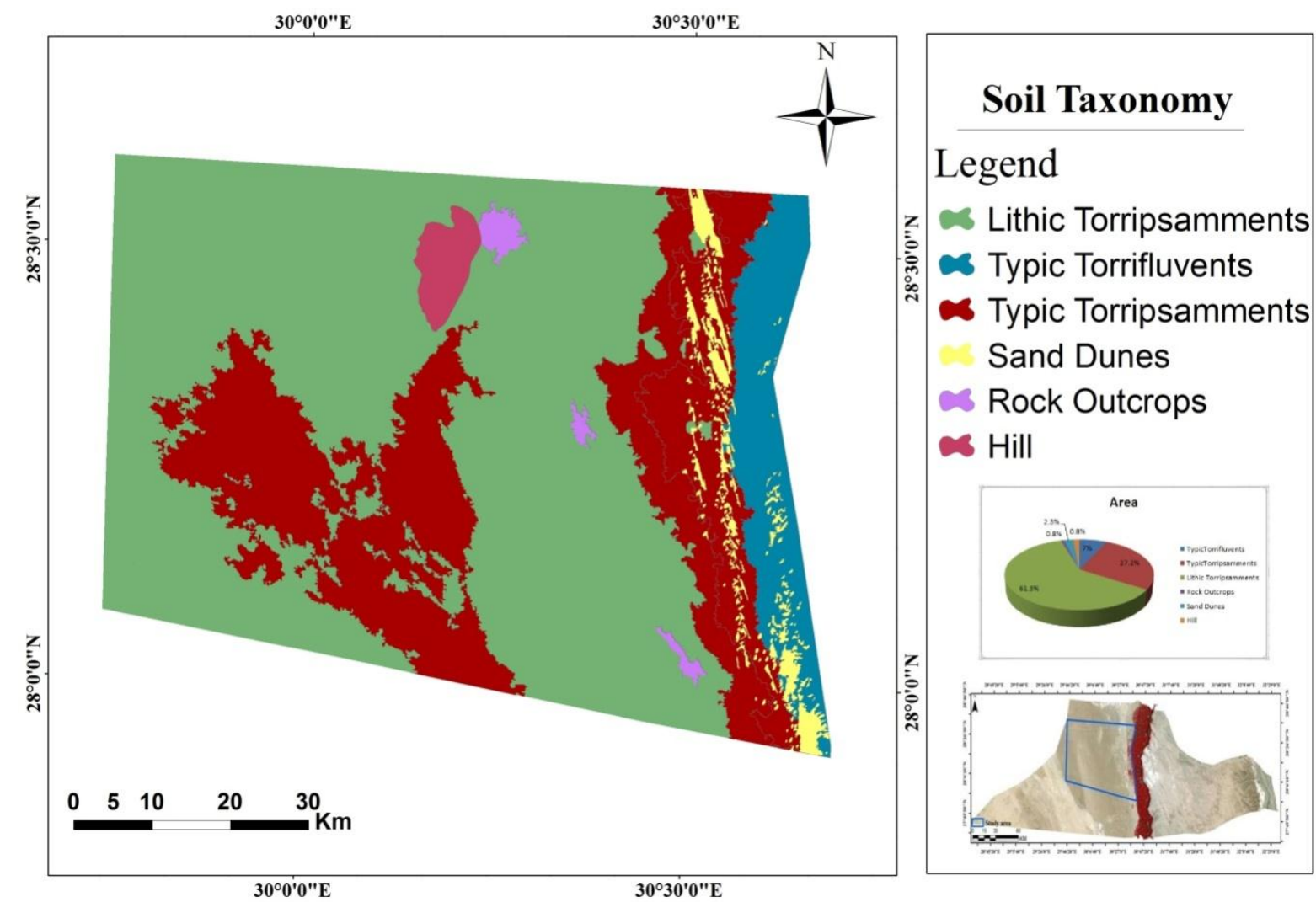

Fig. 6: Soil map of El-Minya Governorate.

Geomorphologic features.

Geomorphologic features could be specified by explaining satellite image. The geomorphic units were specified by analyzing the landscape taken away from visible interpretation of satellite image above the digital elevation model (DEM) to obtain the natural 3D terrain with the assistance of the different topographic maps and field work survey. Results showed that the study area consists of ten geomorphologic units of which three are excluded from the study namely Sand dunes, Hill and Rock out crops due to their non-suitability for cultivation, attaining a total area of $8.5 \%$ (Table 8 and Figure 6).

Table 8. Geomorphic units and Mapping units and their areas and percentages of the total study area

\begin{tabular}{lccc}
\hline GeomorphologicalUnits & Mapping units & $\begin{array}{c}\text { Area } \\
(\text { ha) }\end{array}$ & $\begin{array}{c}\text { Area } \\
(\%)\end{array}$ \\
\hline Old wadi Sediments & WS & 30680.2 & 5.4 \\
Peniplain & P & 42168.6 & 7.4 \\
old river terraces & RT & 40021.3 & 7.0 \\
Shoulders & S & 88170.1 & 15.4 \\
Sand sheets & SH & 35654.4 & 2.3 \\
Rock outcrops & RO & 4792.6 & 0.8 \\
Sand dunes & SD & 13092.9 & 6.2 \\
Erosional Plains & EP & 89196.3 & 15.6 \\
Hill & H & 8317.2 & 1.5 \\
Plain_outwash & PO & 220531.1 & 38.5 \\
\hline \multicolumn{1}{c}{ TOTAL } & --- & 572624.6 & 100 \\
\hline
\end{tabular}




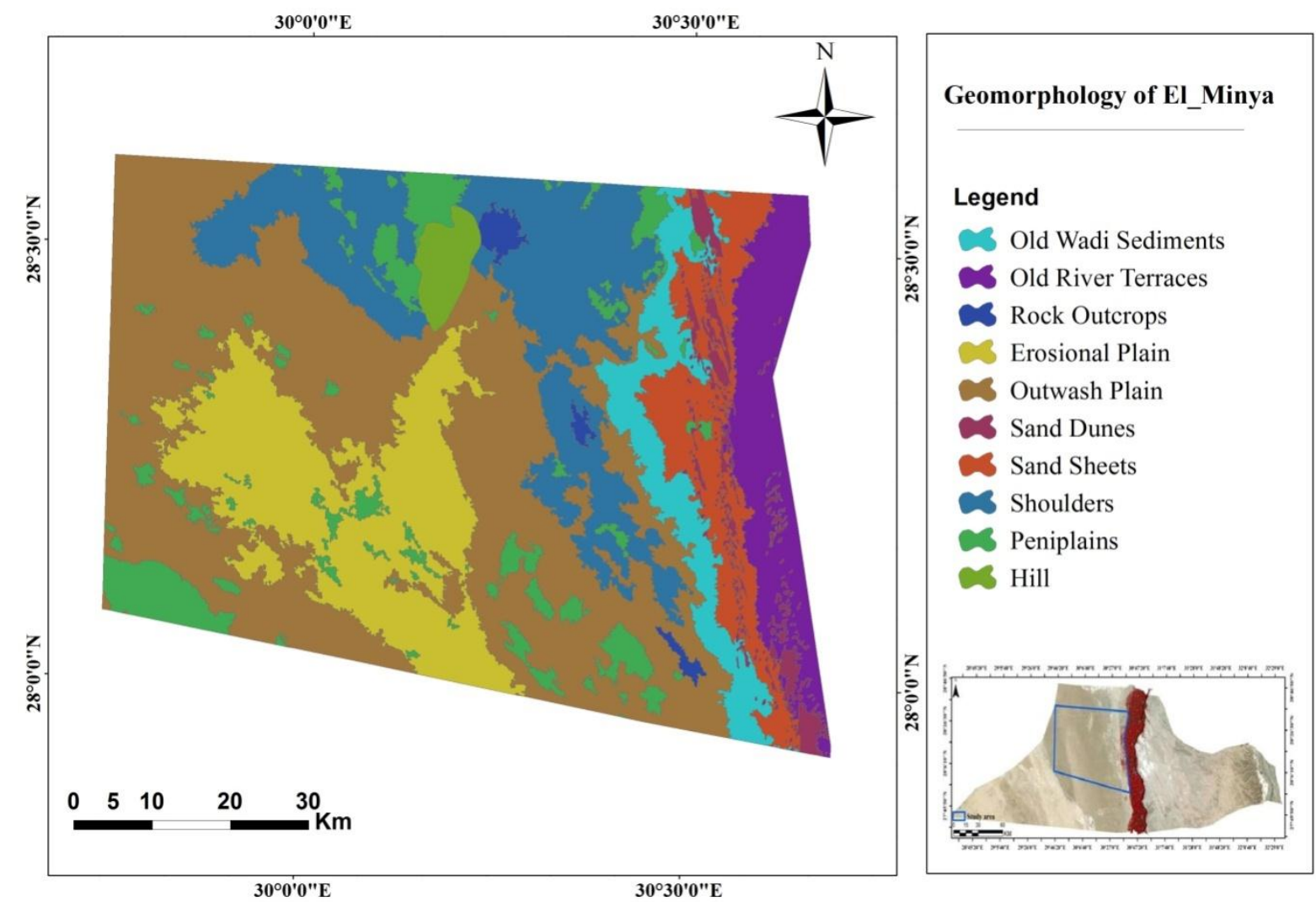

Fig. 6: Geomorphology of the El-Minya Governorate

\section{NDVI in the studied area}

It can be inferred on Soil quality from the vegetation quality using the Normalized Difference Vegetation Indices (NDVI). NDVI obtained from the satellite remote sensing data Landsat- 8 image data (bands 4and 5) acquired in 2019 were used to compute the NDVI of the study areas while the detailed soil classification map produced was used to estimate soil fertility. The soil classification provided sufficient detailed for the analysis. The values obtained can be divided as follows: $0-0.2$ bare land and 0.2-0.7 vegetation land while negative values are evidence of water (Linag, 2004). The soil classes were regrouped based on potential for the soil to release nutrients for crop use for example a well-drained soils, with high percentage of loam is considered more fertile than a well-drained sandy soils. The soil classes were also indexed based on the potential of the soil to free nutrients for plant use. The calculated NDVI for the study area is shown in Figure (7). 


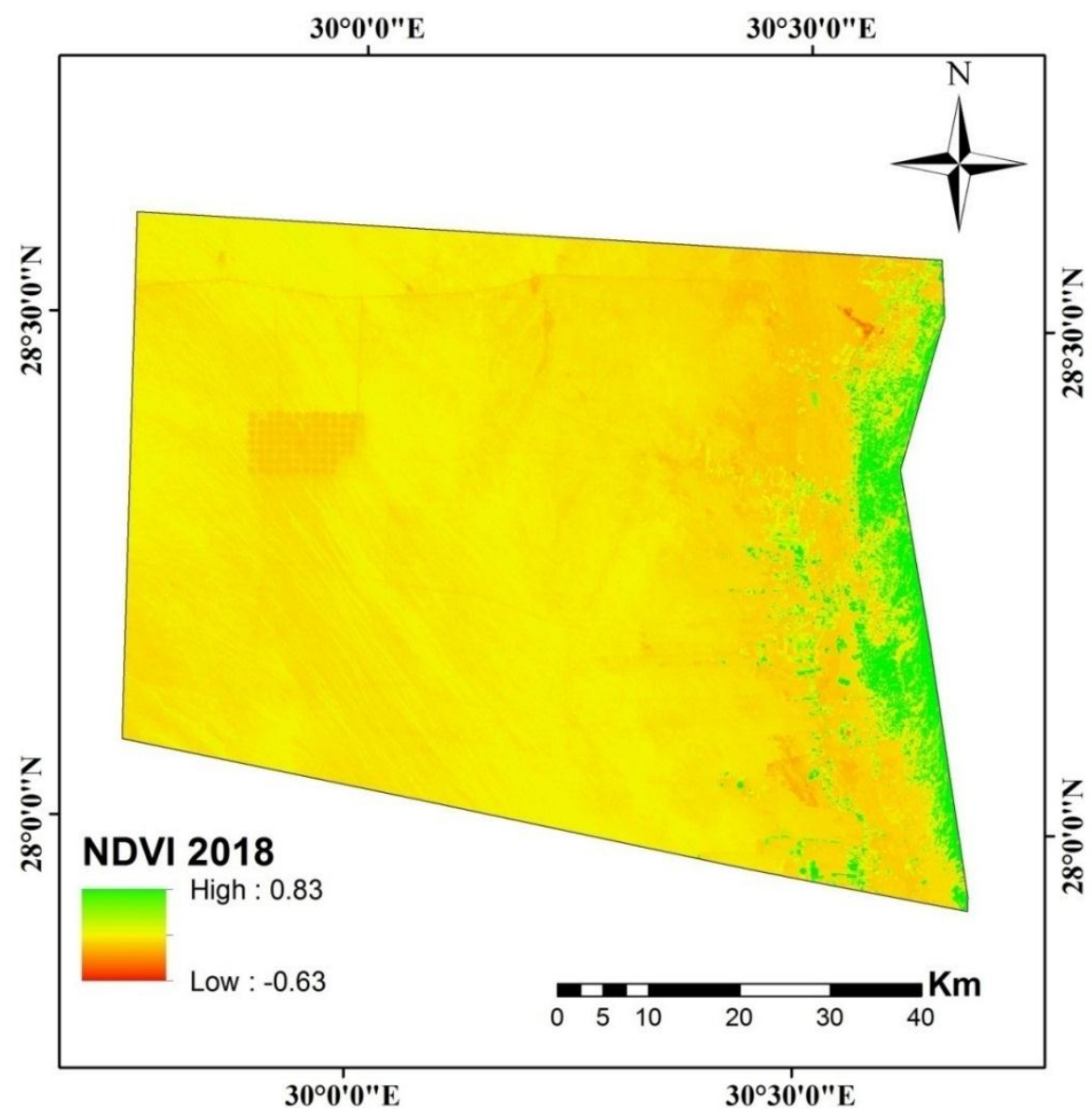

Fig. (7): NDVI of the studied area

\section{Assessment of soil quality}

The soil quality index (SQI) was evaluated depending upon drainage condition, rock fragments (\%) slope gradient (\%), soil texture class, soil depth $(\mathrm{cm})$, parent material, EC $(\mathrm{ds} / \mathrm{m}), \mathrm{ESP}, \mathrm{pH}$ and $\mathrm{CaCO}_{3}$. The results indicate that the areas of high soil quality index (I) $(\mathrm{SQI}<1.2)$ represent $7.0 \%$ of the total area (40021.3 ha) in RT mapping unit. Most of the study area (29\%, 165993 ha) was classified as moderately quality class (II) in terms of soil quality index (SQI = 1.2-1.25) mainly presented in WS, EP and PO mapping units. Most of the study area was classified as moderate low quality (III SQI 1.251.5)(59\% 340408 ha) in P, S and SH mapping unit.
Finally, the areas of low soil quality index (III) (SQI >1.45) represents $8.5 \%$ of the total area (26202.7 ha) associated with RO, SD and H mapping units. The present study demonstrates that more than $90 \%$ of El-Minya has high quality lands for agricultural purposes. Table13 illustrates SQI levels showing a remarkable fluctuation ranging from "high" to "low" due to the variety of limiting factors. The low soil quality dominates the areas characterized by sandy texture, shallow depth and poor drainage. The parametric evaluation system of the index was given in Tables 9 to 11, while table 12and Figure10represent the layer of soil quality index of the study area as exported from Arc GIS.

Table 9.Values of the factors of soil quality index of the studied soils of Minya area

\begin{tabular}{|c|c|c|c|c|c|c|c|c|c|c|}
\hline $\begin{array}{l}\text { Mappin } \\
\mathrm{g} \quad \text { unit }\end{array}$ & Depth & slope & $\begin{array}{l}\text { Rock } \\
\text { fragments }\end{array}$ & Drainage & Texture & $\begin{array}{l}\text { Parent } \\
\text { material }\end{array}$ & $\mathrm{EC}(\mathrm{ds} / \mathrm{m})$ & $\overline{\text { ESP }}$ & pH & $\begin{array}{l}\mathrm{CaCO}_{3}(\mathrm{~g} / \mathrm{kg} \\
)\end{array}$ \\
\hline RT & 120 & 1 & 18 & $\begin{array}{l}\text { imperfectly } \\
\text { drainage }\end{array}$ & Clay loam & limestone & 3.95 & 9.26 & 8.12 & 20.43 \\
\hline SH & 60 & 1.33 & 40 & Well drainage & Sand & $\begin{array}{l}\text { Sandy } \\
\text { formation }\end{array}$ & 1.4 & 9.15 & 8.24 & 23.17 \\
\hline WS & 70 & 1 & 18.8 & Well drainage & Sand & $\begin{array}{l}\text { Sandy } \\
\text { formation }\end{array}$ & 1.64 & 9.80 & 8.15 & 22 \\
\hline $\mathbf{P}$ & 65 & 1.66 & 45 & Well drainage & Sand & $\begin{array}{l}\text { Sandy } \\
\text { formation }\end{array}$ & 1.89 & 8.40 & 8.13 & 23.13 \\
\hline $\mathbf{S}$ & 65 & 1.2 & 30 & Well drainage & Sand & $\begin{array}{l}\text { Sandy } \\
\text { formation }\end{array}$ & 1.59 & 9.73 & 8.21 & 24.68 \\
\hline EP & 106 & 1 & 20 & Well drainage & Sand & $\begin{array}{l}\text { Sandy } \\
\text { formation }\end{array}$ & 1.98 & 9.62 & 8.24 & 21.85 \\
\hline PO & 78 & 1.4 & 37 & Well drainage & Sand & $\begin{array}{l}\text { Sandy } \\
\text { formation }\end{array}$ & 1.83 & 9.11 & 8.08 & 23.88 \\
\hline
\end{tabular}


There are ten effective physical and chemical factors for assessing soil quality as follow;

Soil drainagesof the study area is falling in the class of well drainage soil and small area of soil is imperfectly drainage and there a small area somewhat excessive drainage. The spatial distribution of soil drainage is shown in Fig.8.

Parent material the study area is located in two classes; the eastern part is Alluviums and Colluviums and the other part is Sandy formation. This means that the parent material is imperfectly for agriculture. The spatial distribution of Parent material is shown in Fig.8.

Texture Whole of study area is sandy texture but eastern part is clay loam as assessed based on the laboratory analysis. The spatial distribution of soil texture is shown in Fig.8.

Depth The soils of the study area were moderately deep to very deep. The variety in depth was attributed to the aspect of topography and physiography. This is mainly arisen from the lack of adequate water for prolonged period on upland soils associated with removal of finer particles and their deposition. The spatial distribution of soil depth is shown in Fig.8.

Slope The slope of the study area is more close to a gentle slope which is more suitable for reclamation and cultivation. The spatial distribution of Slope is shown in Fig.8.

Rock and fragments the area is occupied by very small gravel class having between 35 and 60 percentages. The eastern region of the investigated area is covered by non-gravelly or slight gravel class having less than 15 percentage gravels, and a small part of the area soils covered by moderate gravelly class having between 15 to 35 percentages of gravels. The spatial distribution of Rock and fragmentsin the study area is shown in Fig.8.

Table 10. Soil characteristics of the investigated area

\begin{tabular}{lllllllllll}
\hline $\begin{array}{l}\text { Mappin } \\
\text { g unit }\end{array}$ & Depth & Slope & $\begin{array}{l}\text { Rock } \\
\text { fragments }\end{array}$ & Drainage & Texture & $\begin{array}{l}\text { Parent } \\
\text { material }\end{array}$ & $\begin{array}{l}\mathbf{E C}(\mathbf{d s} / \mathbf{m} \\
)\end{array}$ & $\begin{array}{l}\mathbf{E S} \\
\mathbf{P}\end{array}$ & $\begin{array}{l}\mathbf{p H} \\
\mathbf{C a C O}(\mathbf{g} \\
\mathbf{k g g})\end{array}$ \\
\hline RT & P1 & S1 & R1 & D2 & T1 & M1 & C1 & E1 & H3 & O1 \\
SH & P2 & S1 & R2 & D1 & T4 & M3 & C1 & E1 & H3 & O1 \\
WS & P2 & S1 & R1 & D1 & T4 & M3 & C1 & E1 & H3 & O1 \\
P & P2 & S1 & R2 & D1 & T4 & M3 & C1 & E1 & H3 & O1 \\
S & P2 & S1 & R2 & D1 & T4 & M3 & C1 & E1 & H3 & O1 \\
EP & P1 & S1 & R2 & D1 & T4 & M3 & C1 & E1 & H3 & O1 \\
PO & P1 & S1 & R2 & D1 & T4 & M3 & C1 & E1 & H3 & O1 \\
\hline
\end{tabular}

Table 11. Assessment of soil quality index of the study area

\begin{tabular}{|c|c|c|c|c|c|c|c|c|c|c|c|c|}
\hline $\begin{array}{c}\text { Mappi } \\
\text { ng unit }\end{array}$ & Depth & Slope & 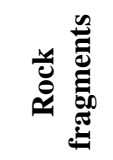 & 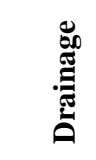 & 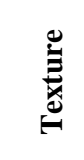 & 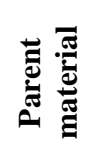 & 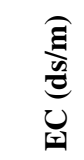 & $\hat{7}$ & 涪 & లో & $\hat{\theta}$ & تేّ \\
\hline RT & 1.00 & 1.00 & 1.00 & 1.33 & 1.00 & 1.00 & 1.00 & 1.00 & 1.66 & 1.00 & 1.05 & I \\
\hline SH & 1.33 & 1.00 & 1.33 & 1.00 & 2.00 & 2.00 & 1.00 & 1.00 & 1.66 & 1.00 & 1.28 & III \\
\hline WS & 1.33 & 1.00 & 1.00 & 1.00 & 2.00 & 2.00 & 1.00 & 1.00 & 1.66 & 1.00 & 1.24 & II \\
\hline $\mathbf{P}$ & 1.33 & 1.00 & 1.33 & 1.00 & 2.00 & 2.00 & 1.00 & 1.00 & 1.66 & 1.00 & 1.28 & III \\
\hline $\mathbf{S}$ & 1.33 & 1.00 & 1.33 & 1.00 & 2.00 & 2.00 & 1.00 & 1.00 & 1.66 & 1.00 & 1.28 & III \\
\hline EP & 1.00 & 1.00 & 1.33 & 1.00 & 2.00 & 2.00 & 1.00 & 1.00 & 1.66 & 1.00 & 1.24 & II \\
\hline PO & 1.00 & 1.00 & 1.33 & 1.00 & 2.00 & 2.00 & 1.00 & 1.00 & 1.66 & 1.00 & 1.24 & II \\
\hline
\end{tabular}

Table12. Distribution of soil quality index of the study area

\begin{tabular}{|c|c|c|c|c|c|}
\hline (SQI) & Grade & Class & Mapping unit & Area (ha) & Area \% \\
\hline$>1.2$ & $\mathbf{I}$ & High quality & RT & 40021.3 & 7.0 \\
\hline $1.2-1.25$ & II & Moderate quality & WS, EP and PO & 165993 & 29 \\
\hline 1.25-1.5 & III & $\begin{array}{c}\text { Moderately low } \\
\text { quality }\end{array}$ & $P, S$ and $S H$ & 340408 & 59 \\
\hline$<1.5$ & IIII & Low quality & RO, SD and H & 26203 & 5 \\
\hline
\end{tabular}



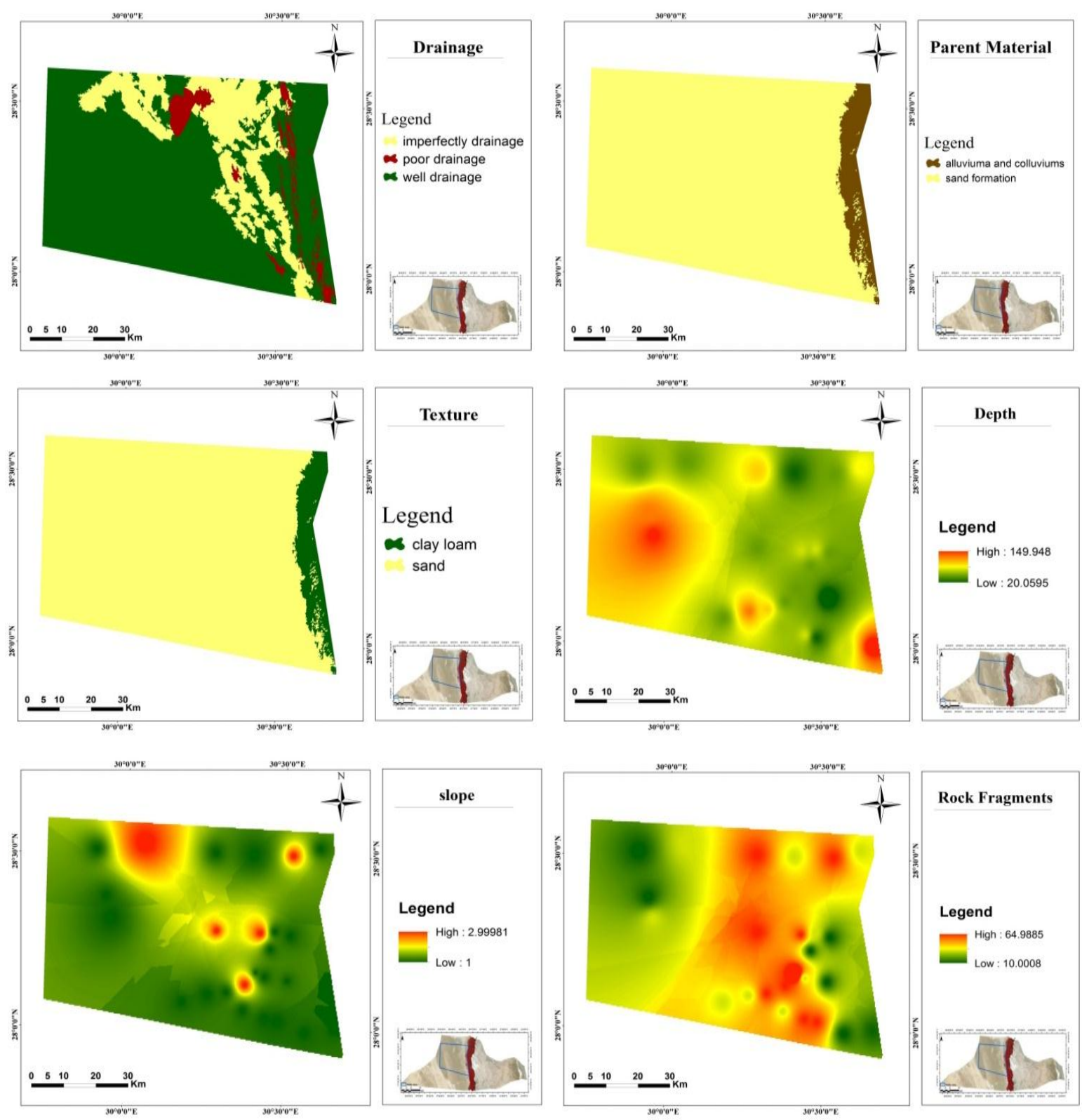

Fig. 8: Spatial distribution of soil physical parameters in the study area.

EC (ds/m) Salinity is one of the main limiting factors for agriculture in the arid and semi-arid zone. EC values for weight average of different profiles ranged from 0.19 to $3.04 \mathrm{ds} \mathrm{m}^{-1}$ which indicates that these soils are non-saline in nature, which might be due to free drainage conditions which favored the removal of released bases by filtrate water that determines the quality of study area for different agricultural crops. The spatial distribution of mean EC in the study area is shown in Fig.9.

ESP It is expressed as: $\mathrm{ESP}=$ [exchangeable sodium (meq/100g soil) / cation exchange capacity (meq/ $100 \mathrm{~g}$ soil)] x 100.ESP values ranged from 7.5 to 12.3 which indicate that these soils are non-saline in nature. The spatial distribution of ESP is shown in Fig.9.

pH Results of lab analyses showed that soil $\mathrm{pH}$ is moderately alkaline. There was much variation in the $\mathrm{pH}$ with the depth. The increase in $\mathrm{pH}$ with depth might be attributed to intense and uniform leaching of bases throughout the profile. The spatial distribution of soil $\mathrm{pH}$ is shown in Fig.9. 

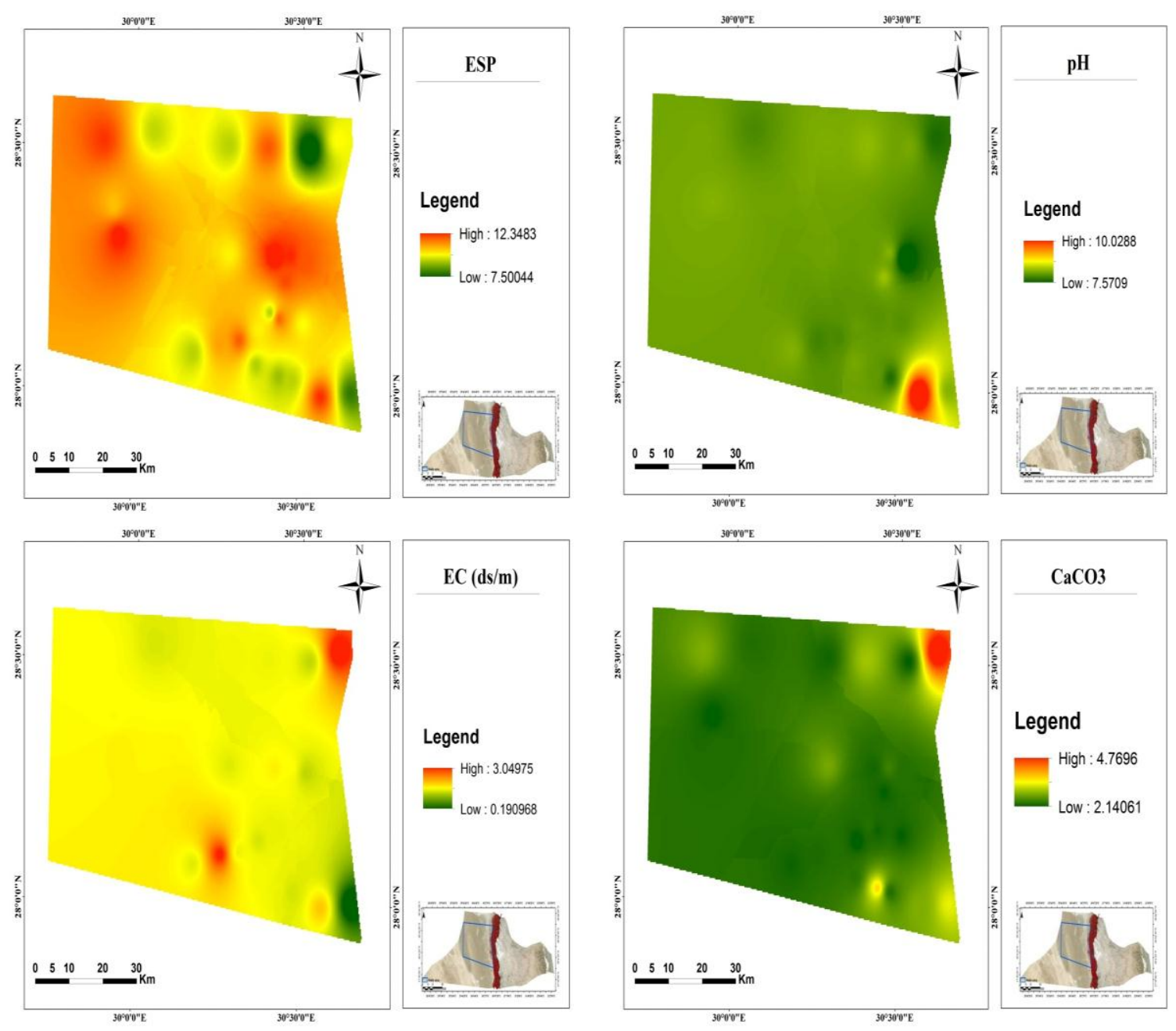

Fig. 9: Spatial distribution of soil chemical parameters in the study area.
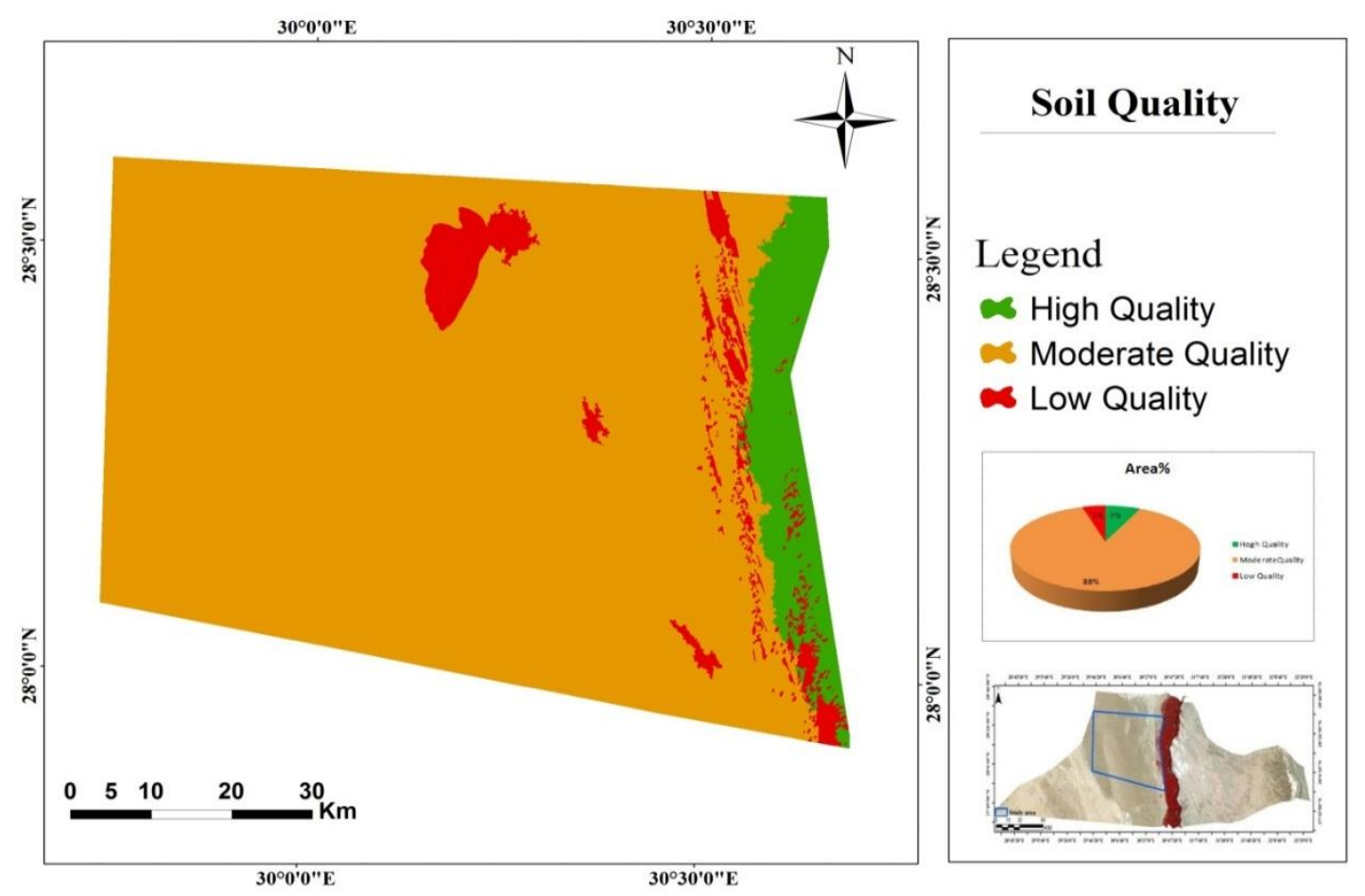

Fig.10: Soil quality map of El-Minya area. 


\section{Conclusion}

GIS and Remote sensing are very helpful to collect, store, manage, retrieve, analyze, output the huge amounts of geospatial data, field observation sand quantitatively evaluates soil quality of El-Minya area, western Desert of Egypt west of Nile valley. Results indicate a possibility of agricultural expansion. About $91.6 \%$ of the area is good for agriculture utilization. The main soil quality limitations are texture, slope, depth, parent material, drainage, $\mathrm{EC}, \mathrm{PH}, \mathrm{CaCO}_{3}$ and ESP. The study area will be of a great value in regard of governmental plans if the development is planned in a manner that takes benefits of the natural resources without threatening their quality.

\section{Acknowledgment}

I would like to express my deepest thanks to Sincere thanks are due to Mohamed El-Sayed Mohamed Galhoum and Mostafa Abdou Abdellatif Ahmed Researcher at National Authority for Remote Sensing and Space Sciences (NARSS), Egypt for their help this work.

\section{References:}

Abdel Rahman, M.; Natarajan ,A.; Srinivasamurthy, CA, M.,Natarajan, A.;Rajendra, $\mathbf{H}$ and Prakash, SS .2018 .Assessment of Soil Quality by Using Remote Sensing and GIS Techniques A Case study, Chamrajanagar District, Karnataka, India. Acta Scientific Agriculture. 2(1): 05-12.

AbouHeleika, M.M., and Niesner, E.2008. Configuration of the Limestone Aquifers in the Central Part of Egypt Using Electrical Measurements. Hydrogeology Journal, 17: 433-6.

Atanu, M. and Lal, R. 2014.Comparison of soil quality index using three methods.PloS one Public Library of Science, 9 (8):105-981

Bandyopadhyay, P. C.2007. Soil analysis.Amazon Co. London, UK.

Blum, W. 2003. European soil protection strategy, J. Soils Sediments, 3: 242.

Blum,W.E.H. 2006. Soil resources - The basis of human society and the environment.Bodenkultur,57: 197-202.

Bone, J., Head, M.; Barraclough, D.; Archer, M.,Scheib, C.; Flight, D and Voulvoulis, N.2010. Soil quality assessment under emerging regulatory requirements, Environ. Int., 36: 609-622.

Data provided by weather station: 623870.2017.https://fr.tutiempo.net/climat/ws623870.html

Dengiz, O.; Ozcan, H.;Köksal, E.S.;Baskan, O and Kosker, Y. 2010. Sustainable natural resource management and environmental assessment in the Salt Lake (TuzGolu) specially protected area.
Journal of Environmental Monitoring and Assessment, 161: 327-342.

Dewan, A. M. and Yamaguchi, Y.2009. Using remote sensing and GIS to detect and monitor land use and land cover change in Dhaka Metropolitan of Bangladesh during 1960-2005. Environmental monitoring and assessment, 150(1): 237-249.

Doran, J.W and Parkin, T.B.1994. Defining and assessing soil quality. Defining soil quality for sustainable environment. Soil Science Society of America (SSSA), 35: 3-21.

Drury, C. F.; Zhang,T. Q and Kay,B. D.2003.The nonlimiting and least limiting water range oil nitrogen mineralization. Soil SciSoc Am. J., 67:1388-1404.

Ekanayake, G.K. and Dayawansa, N. D. K.2003. Department of Agricultural Engineering, Faculty of Agriculture, University of Peradeniya, Peradeniya Sri Lanka.Map India Conference.Land suitability identification for a production forest through GIS Technique.J.Geos. Wor: 1-28

EMA. 2010. Climatic atlas of Egypt. Egypt Meteorological Authority (EMA). Cairo, Egypt.

FAO. 2006. Guidelines for soil description. 4thEd.Food and Agriculture Organization (FAO)of the United Nations, Rome, Italy.

Huddleston, J.H. 1984. Development and use of soil productivity ratings in the United States, Geoderma, 32: 297-317.

Jones, M and Philpot, D.W.2015. Alinear physicallybased model for remotesensing of soil moisture using short wave infrared bands. Rem. Sens. Environ.164:66-76.

Karlen, D. L.; Mausbach, J. W.; Doran, J. W. G.; Harris,R. F. and Schuman ,G. E. 1997. Soil quality: A concept, definition and framework for evaluation. Soil Sci. Soc. Am. J. 61: 4-10.

Khatami,R.; Mountrakis, G. and Stehman, S. V. 2016. A meta-analysis of remote sensing research on supervised pixel-based land-cover image classification processes: General guidelines for practitioners and future research. Rem. Sen. Environ, 17: 89-100.

Kosmas, C. Ferrara, A. Briasouli, $H$ and Imeson, A .1999. Methodology for mapping environmentally sensitive areas (ESAs) to desertification.Mediterranean Desertification and Land Use (MEDALUS), European Union .18882 : 31.

Larson, W.E. and Pierce, F.J. 1994. Dynamics of soil quality as a measure of sustainable management. Defining soil quality for sustainable environment. Soil Science Society of America (SSSA), 35: 37-51.

Lillesand, T.M. and Kiefer, R.W.2007.Remotesensingandimage interpretation, 5th Ed., JohnWiley, NY, USA.

Lillesand, T.M. and Kieffer, R.W.1994. Remote sensing and image interpretation. 3rd ed. John Wiley and Sons, New York 
Linage, S. (2004). Quantitative remote sensing of land surface. Wiley, New Jersey, 479-501 PP.

MacDonald, K.B.; Frazer, W.; Lelyk, G and Wang, F.1995.A geographic framework for assessing soil quality. Agriculture and Agri-Food Canada. Ottawa, Canada, 19-30.

Mulder, V.L.; de-Bruin, S.; Schaepman, M.E. and Mayr, T.R. 2011. The use of remote sensing insoil and terrain mapping: A Review. Geoderma, 162(12):1-19.

Novak, P.,Vopravil, J. and Lagova, J.2010. Assessment of the soil quality as a complex of productive and environmental soil function potentials. Soil \& Water Res., 5 (3): 113-119.

Pierzynski, G. M.; Sims, J.T and Vance, G.F.1994. Soils and environmental quality. Lewis Publishers, CRC Press, Boca Raton, Florida

Randall, B. 2012. Introduction to remote sensing of Environment (RSE), Micro images Inc.

Rindfuss, R. R.; Walsh, S.J.; Turner B.L.; Fox, J. and Mishra,V.2004. Developing a science of land change: challenges and methodological issues. Proceedings of the National Academy of Sciences of the United States of America, 101(39): 1397613981.

Rozentstein,O.; Siegal, Z.; Blumberg, D.G. and Adam, J. 2016.Investigating the backscatter contrast anomaly in Synthetic Aperture Radar (SAR) imagery of the dunes along the IsraelEgypt. Int. J. Appl. Earth Obser.Geoinf, 46:13-21.

Said, R. 1983. Remarks on the origin of the landscape of the eastern Sahara. - J. African Earth Sciences, 1:153-158.

Said, R. 1997. The Geological Evolution of the River Nile. Springer-Verlag.

Said, R., 1981. The Geological evolution of the River Nile. Springer-Verlag, pp. 151, New York

Shabana, A.R. 2010.Hydrogeological Studies on the Area West DeirMouas-Mallawi, El Mania Governorate, Egypt. Egyptian Journal of Geology, $54,61-78$.
Singh, M. J. and Khera, K. L.2009. Physical indicators of soil quality in relation to soil erodibility under different land uses. Arid Land Res Manag, 23: 152-167.

Soil Survey Staff. 2000. Soil ratings for plant growth, a system for arraying soils according to their inherent productivity and suitability for crops. Holzhey and Sinclair (eds.), USDA Natural Resources Conservation Service, National Soil Survey Center, Lincoln, NE.

Taghizadeh- Mehrjardi, R.; Minasny, B.; Sarmadian, F. and Malone, B.P.2014.Digitalmapping of soil salinity in Ardakan region, central Iran.Geoderma,213:15-28.

Tottrup, $\mathrm{C}$ and Rasmussen, M.S.2004. Mapping long-term changes in savannah crop productivity in Senegal through trend analysis of time series of remote sensing data. Agriculture, Ecosystems \& Environment, 103(3): 545-560.

UNDP. 2007. Globalization, agriculture and the least developed countries. United Nations. Ministerial Conference of the LDCs. Making Globalization Work for the LDCs, Issues Paper, $12 \mathrm{p}$.

USDA. 2004. Soil survey laboratory methodsmanual. Soil Survey, United State Department of Agriculture (USDA), Rep.No.42, Version 4.0.

USDA.2004. Soil survey laboratory methods manual. Soil Survey, United State Department of Agriculture (USDA), Rep.No.42, Version 4.0.

Wander, M. M.; Walter, G.L.; Nissen, T.M.; Bollero, G.A and Andrews, S.S.2002. Soil quality: Science and Progress. Agronomy Journal, 94: 23-32.

Warkentin, B.P.1992. Soil science for environmental quality - how do we know what we know. Journal of Environmental Quality, 21: 163-166.

Wilson, J. P and Fotheringham, A.S.2008. The handbook of geographic information science. John Wiley \& Sons. 


\section{تقييم مؤثرات جودة التربة في محافظة المنيا باستخدام التكامل بين نظم المعلومات الجغرافية والاستثعار عن البعد.}

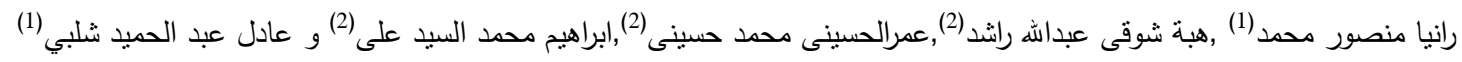

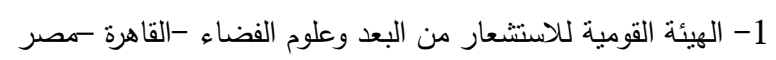

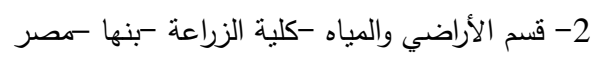

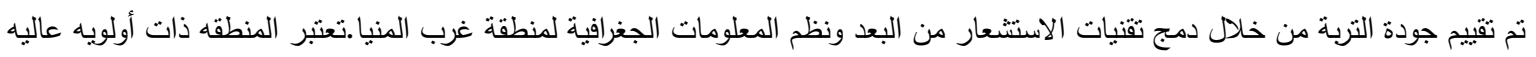

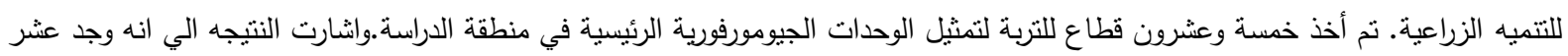
وحدات جيمورفولوجيه وهى 1-رواسب الاوديه القديمه 2-السهل الحصوى 3-المصاطب النهريه القيمه 4-الصائح الرمليه 5-الكثبان الرمليه 6-

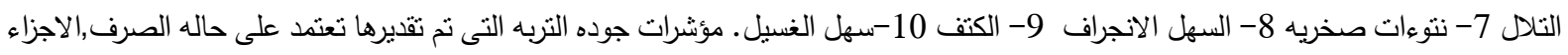

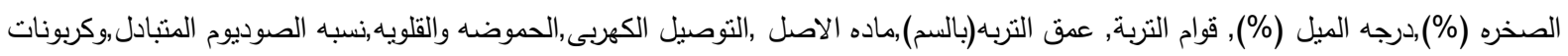

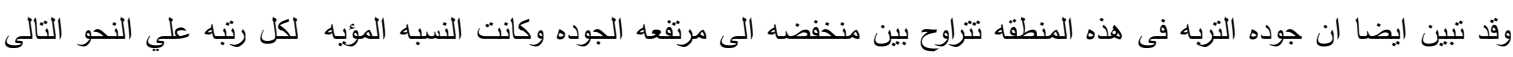

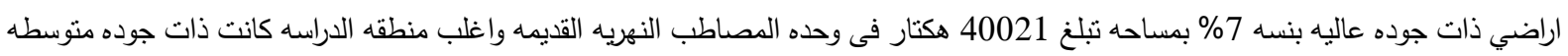

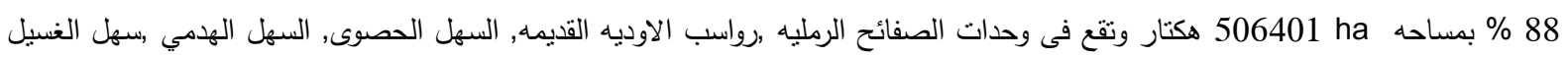

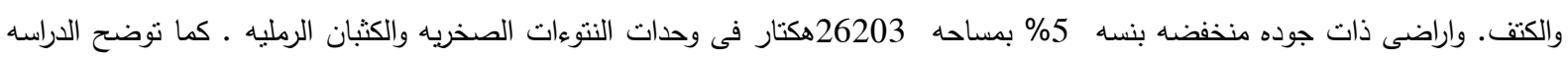

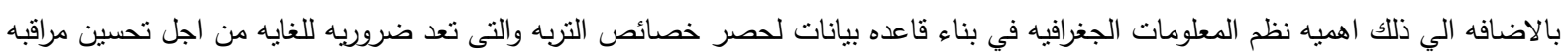

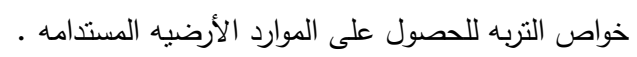
كلمات البحث: جودة التربة ، الاستشعار عن بعد ، نظم المعلومات الجغرافية ، محافظة المنيا 